\section{Editorial}

*Corresponding author

Anna Barbaro, PhD

Department of Forensic Genetics

Studio Indagini Mediche E Forensi (SIMEF)

President of the Worldwide Association of Women Forensic Experts (WAWFE)

Traversa Li Nicolo, 4

89129 Reggio di Calabria RC, Italy

E-mail: president@wawfe.org

Volume 1 : Issue 1

Article Ref. \#: 1000TFMOJ1e006

\section{Article History}

Received: August $26^{\text {th }}, 2016$

Accepted: August 26 ${ }^{\text {th }}, 2016$

Published: August 26 ${ }^{\text {th }}, 2016$

\section{Citation}

Barbaro A. Overview on progress in forensic deoxyribonucleic acid analysis. Toxicol Forensic Med Open J. 2016; 1(1): e14-e15. doi: 10.17140 TFMOJ-1-e006

\section{Copyright}

(C2016 Barbaro A. This is an open access article distributed under the Creative Commons Attribution 4.0 International License (CC BY 4.0), which permits unrestricted use, distribution, and reproduction in any medium, provided the original work is properly cited.

\title{
Overview on Progress in Forensic Deoxyribonucleic Acid Analysis
}

Anna Barbaro, PhD*

Department of Forensic Genetics, Studio Indagini Mediche E Forensi (SIMEF), President of the Worldwide Association of Women Forensic Experts (WAWFE), Traversa Li Nicolo, 4, 89129 Reggio di Calabria RC, Italy

Forensic science is "the application of science to criminal and civil laws".

The field is very extensive and cover different disciplines including medicine, biology, chemistry, physics.

Medical examination of bodies (forensic medicine) in order to determine cause and time of a suspicious death have been used for centuries, while the use of science to investigate crimes in order to identify criminals began in the mid to late 1800 's.

The major advancement in forensic science occurred in the late 1980's when scientists were able to investigate human genome deoxyribonucleic acid (DNA).

Prof. Alec Jeffreys, from the University of Leicester identified in the human genome some sequences repeated in a variable number tandem repeats (VNTR).

He developed a procedure called "DNA fingerprinting" that was firstly used in a forensics in 1987 in UK for solving a double murder case occurred in Leicestershire. Colin Pitchfork is known to be the first person convicted of a crime based on DNA fingerprinting evidence.

Forensic DNA analysis was revolutionized by the introduction of the polymerase chain reaction (PCR), developed by Murris, that enables the production of millions of copies of a specific DNA sequence allowing the analysis also of DNA traces.

DNA analysis permits now-a-days the identification of a person through biological fluids, hair, human remains and also skin cells left on touched objects (contact trace).

Since its first application, DNA analysis has played a crucial role not only in the investigation of violent crimes but also in case of mass disasters victims identification (DVI), for the reconstruction of controversial biological relationships and for the creation of DNA databases useful in the fight against crime.

Short tandem repeats (STRs) are the most widely used markers for forensic DNA testing, but also other genetic polymorphisms, such as the ones in the mitochondrial DNA (mtDNA) genome or in sexual chromosomes (X-Y) provide useful results.

A common problem in forensics concerns the genetic identification of degraded biological samples such as the material collected at the crime scenes or recovered from mass disaster that may have been remained exposed to harsh environmental conditions (sunlight, humidity, etc.) damaging DNA structure.

In this perspective, not only the range of genetic markers used is increased with the introduction of mini-STR and SNPS analysis but new automated high-throughput analytical methods (i.e. next generation sequencing) have been developed in order to increase the ability to recover 
informations from biological samples even if degraded or in small quantity.

Recently, the analysis of SNPs useful for ancestry identification or for physical characteristics determination (i.e. hair, eye or skin colour) have been introduced: this offers a powerful new tool in forensics to connect a suspect with a crime scene or to identify human remains.

The availability of new procedures has also a great impact in "defrosting" unsolved cold cases: new sensitive testing methods are applied to the analysis of old samples often allowing the case resolution after a long time.

In addition to allow a rapid identification of suspects directly at crime scene or for DNA database purposes, portable rapid DNA devices have been developed, in order to obtain a full DNA profile anywhere in under 2 hours from a reference sample (buccal swab). 